\title{
PREVALENCE OF KIR2DL2/DS2 AND KIR2DL3 AND PRESENCE OF B19V IN PATIENTS WITH THYROID DISORDERS
}

\author{
Sabīne Grāvelsinga ${ }^{1, \#}$, Elisabetta Caselli ${ }^{2,3}$, Zaiga Nora-Krūkle ${ }^{1}$, Simons Svirskis ${ }^{1}$, \\ Anda Vilmane ${ }^{1}$, Dario Di Luca ${ }^{2}$, Modra Murovska ${ }^{1}$ \\ ${ }^{1}$ Institute of Microbiology and Virology, Rīga Stradiṇš University, 5 Rātsupītes Str., Rīga, LV-1067, LATVIA \\ ${ }^{2}$ Department of Chemical and Pharmaceutical Sciences, University of Ferrara, via L. Borsari $46-44121$, Ferrara, ITALY \\ ${ }^{3}$ Department of Medical Sciences, University of Ferrara, via L. Borsari $46-44121$, Ferrara, ITALY \\ \# Corresponding author sabine.gravelsina@rsu.lv
}

Contributed by Modra Murovska

The functions of human natural killer cells are controlled by diverse families of antigen receptors. Prominent among these are the killer cell immunoglobulin-like receptors (KIR), controlled by a family of genes clustered in one of the most variable regions of the human genome - on chromosome 19q13.4. This study aimed to investigate the possible interplay between KIR allotype, B19 infection, and thyroid disorders. Thyroid gland tissue of 30 patients with autoimmune thyroid gland diseases (AITD), 30 patients with non-autoimmune thyroid gland diseases (non-AITD) and 30 deceased subjects whose histories did not show any of autoimmune or thyroid diseases (control group) were enrolled in the study. The presence of B19V, KIR2DL2/DS2, and KIR2DL3 was detected using PCRs (nPCR, PCR). The results showed that $28 \%$ of samples of thyroid tissue from patients with AITD and $67 \%$ with non-AITD were positive for the presence of B19V, in contrast only 5\% control tissue samples harbored B19V DNA. B19V-positive AITD patients had higher frequency of KIR2DL2/DS2 homozygosity and lower frequency of homozygous KIR2DL3 genotype compared to B19V negative cases (33\% vs $21 \%$ and $17 \%$ vs $46 \%$, respectively). Although our data showed that B19V positive patients with AITD had a higher frequency of homozygosity for KIR2DL2/DS2, further studies with larger groups of patients are necessary to confirm the relationship between KIR, B19V and susceptibility to thyroid disease.

Key words: thyroid diseases, KIR gene, B19V.

\section{INTRODUCTION}

Human parvovirus B19 (B19V) is a small, non-enveloped virus and belongs to the Parvoviridae family. The B19 genome is a linear single-stranded DNA and encodes one non-structural protein (NS) and two viral capsid proteins (VP1 and VP2) (Heegaard and Brown, 2002). B19V has been linked to autoimmune diseases such as autoimmune neutropenia, thrombocytopenia, haemolytic anaemia, and rheumatoid arthritis (Kozireva et al., 2008; Desailloud and Hober, 2009; Naciute et al., 2016). During the last few years, a limited number of studies have suggested that B19V infection may be associated with autoimmune thyroiditis (Wang et al., 2010; Page et al., 2015). Hashi- moto's thyroiditis (HT) is the most common inflammatory disease of the thyroid gland as well as the most common autoimmune thyroid disease (AITD). HT is a widespread multifactorial condition that results from genetic predisposition in combination with environmental risk factors (Desailloud and Hober, 2009). Viral infections are frequently cited as a major environmental factor involved in thyroid gland diseases (Desailloud and Hober, 2009; Ferrari et al., 2017). The presence of $\mathrm{B} 19 \mathrm{~V}$ in the thyroid has been shown, but whether it is implicated in thyroid diseases or is only a spectator is under investigation. On the other hand, killer cell immunoglobulin-like receptors (KIRs) are likely to play a significant role in the control of the immune response, which would explain several reports on the associa- 
tion of KIR with autoimmune diseases, such a scleroderma, type 1 diabetes, rheumatoid arthritis, systemic lupus erythematosus and others (Pellett et al., 2007; Fusco et al., 2010; Fogel et al., 2013). KIRs are transmembrane glycoproteins expressed by natural killer cells and subsets of T cells. Their genes are polymorphic and highly homologous and found in a cluster on chromosome 19q13.4 (Wilson et al., 2000). A total of 17 of these genes have been recognised and named (Marsh et al., 2003). The names given to the KIR genes are based on the structures of the molecules they encode. The first digit following the KIR acronym corresponds to the number of Ig-like domains in the molecule and the 'D' denotes 'domain'. The D is followed by either an ' $L$ ' indicating a 'Long' cytoplasmic tail, an ' $S$ ' indicating a 'Short' cytoplasmic tail or a 'P' for pseudogenes. The final digit indicates the number of the gene encoding a protein with this structure. KIR having a long cytoplasmic tail are inhibitory, whereas those having a short cytoplasmic tail are activating. The one exception is KIR2DL4, which can exhibit inhibitory or activating function (Vilches and Parham, 2002). When two or more genes have very similar structures and have very similar sequences, they may be given the same number, but distinguished by a final letter, for example the KIR2DL5A and KIR2DL5B genes (Gómez-Lozano et al., 2002). This study aimed to analyse the possible interplay between KIR allotype, B19V infection and thyroid disorders.

\section{MATERIALS AND METHODS}

Study subjects. Thyroid tissue samples from 30 patients with Hashimoto thyroiditis (HT) [median age 49 years (IQR: 37-59)] and 30 patients with non-autoimmune thyroid gland diseases (non-AITD) (Papillary thyroid carcinoma, adenoma and goiter) [median age 53 years (IQR: 41-62)] who underwent thyroidectomy between December 2010 and June 2015 at Rīga East Clinical University Hospital, Clinic "Gailezers", were enrolled in the study. The exact diagnosis of the thyroid gland pathology was established by histological analysis of resected tissue and analysis of specific autoantibodies [auto-antibodies against thyroid peroxidase (TPO), thyroglobulin (TG), and thyroid stimulating hormone receptor (TSHr)].

Thyroid tissue samples from 30 randomly selected age- and gender-matched deceased subjects without thyroid pathologies (the deceased subject's history did not show any autoimmune or thyroid diseases) who had been autopsied were identified as being eligible for the control group. The study design was approved by the Ethical Committee of Riga Stradiňš University (Ethical Code No. 67 and date of approval 25.10.2012), and written consent was obtained from all of the patients and relatives, respectively.

B19V NS (non-structural protein) gene detection by nested polymerase chain reaction. DNA from thyroid gland tissue samples was isolated by proteinase $\mathrm{K}$ digestion followed by phenol-chloroform extraction and ethanol precipitation, and finally, it was re-suspended into molecu- lar-grade water. The quantity of the DNA was measured spectrophotometrically. To ensure the quality of the DNA, a $\beta$-globin PCR was performed (Saiki et al., 1988). The extracted DNA ( 200 ng/ $\mu \mathrm{L})$ was used as a template in nested PCR (nPCR), using primers amplifying the B19V NS gene sequence as described previously (Barah et al., 2001). The amplified DNA with the expected size (103 bp) was analysed in $1.7 \%$ agarose gel. The sensitivity of the B19V-specific primers was 1-10 copies per reaction (Barah et al., 2001). As a positive control, the purified plasmid vector encoding a specific cloned fragment from B19V genome [AMPLIRUN@ Parvovirus B19V (plasmid) DNA Control; Granada, Spain] was used. As negative controls the DNA samples that were negative for $\mathrm{B} 19 \mathrm{~V}$-specific sequences (DNA obtained from practically healthy B19V-negative blood donors) and water with no DNA template were included in each experiment to exclude the possibility of contamination during PCR.

KIR typing. The presence of KIR2DL2/DS2 and KIR $2 D L 3$ genes was determined by using a gene-specific PCR, as previously described (Caselli et al., 2014; Borghi et al., 2016). Briefly, PCR was performed in a reaction volume of $25 \mu \mathrm{l}$ with a final concentration of $1 \times$ PCR buffer, $1.5 \mathrm{mM}$ $\mathrm{MgCl}_{2}, 200 \mu \mathrm{M}$ dNTP, $0.6 \mu \mathrm{M}$ primers, and $1.25 \mathrm{U}$ per sample Taq polymerase, using $100 \mathrm{ng}$ of total DNA as template. PCR amplification was performed using an Applied Biosystems thermocycler according to the following conditions: initial denaturation for $5 \mathrm{~min}$ at $95^{\circ}$, followed by $20 \mathrm{~s}$ at $97^{\circ} \mathrm{C}, 45 \mathrm{~s}$ at $62^{\circ} \mathrm{C}$, and $110 \mathrm{~s}$ at $72^{\circ} \mathrm{C}$ for the first five cycles; and then $20 \mathrm{~s}$ at $95^{\circ} \mathrm{C}, 45 \mathrm{~s}$ at $60^{\circ} \mathrm{C}$, and $110 \mathrm{~s}$ at $72^{\circ} \mathrm{C}$ for 25 cycles.

The PCR products (with expected size corresponding to $1800 \mathrm{bp}$ for KIR2DL2/DS2 and $850 \mathrm{bp}$ for KIR2DL3) were analysed by ethidium bromide-stained $1 \%$ gel electrophoresis.

Statistical analysis. Statistical analysis was performed using GraphPad Prism v.8.4.2 software for Mac (USA, San Diego, CA). Proportion comparison between groups was done using the Chi square test $\left(\mathrm{Chi}^{2}\right)$, and $p$ values less than 0.05 were considered as statistically significant.

\section{RESULTS}

All thyroid tissues were analysed for B19V presence by nPCR specific for the NS gene. The results showed that 6 of $30(20 \%)$ AITD patients and 14 of $30(46.6 \%)$ patients with non-AITD were B19V positive, clearly showing that B19V DNA can be found in the thyroid gland, independently of whether there was or was not an underlying autoimmune disease (Table 1).

However, the results showed a significantly higher prevalence of B19V in tissue of patients with AITD and nonAITD $\left(\mathrm{Chi}^{2}, p=0.04\right.$ and $p=0.0001$, respectively) compared to the control group, which may suggest possible involvement of B19V in thyroid gland diseases (Table 1). 
Table 1. Analysis of the B19V and KIR genotype. B19V positivity among patients with autoimmune thyroid diseases (AITD), non autoimmune thyroid diseases (non-AITD) and control group subjects (Control). KIR allotypes frequencies in AITD, non-AITD and control patients. DL3 $K I R 2 D L 3$ homozygosity, DL2/DL3 - KIR2DL2/DS2/KIR2DL3 heterozygosity, DL2 - KIR2DL2/DS2 homozygosity, Chi square test: ${ }^{*} \mathrm{Chi}^{2} \mathrm{p}=0.04, * * \mathrm{Chi}^{2} \mathrm{p}=0.0001, * * * \mathrm{Chi}^{2} \mathrm{p}=0.0379, * * * * \mathrm{Chi}^{2} \mathrm{p}=$ 0.0211 , * vs control.

\begin{tabular}{l|c|c|c|c|c}
\hline & B19+ & B19- & DL2 & DL2/DL3 & DL3 \\
\hline AITD (n=30) & $6^{*}$ & 24 & 7 & 11 & 12 \\
Non-AITD $(\mathrm{n}=30)$ & $14 * *$ & 16 & $2 * * * *$ & 9 & $19 * * *$ \\
Control $(\mathrm{n}=30)$ & 1 & 29 & 10 & 10 & 10
\end{tabular}

Regarding the KIR genotype, there were significant differences in KIR allotype frequency in patients with AITD and non-AITD compared to the control group (Table 1). There was also a slight difference in KIR2DL2/DS2 homozygosity between AITD and non-AITD patients -7 of 30 patients and 2 of 30 patients, respectively, but without statistical significance $(p=0.145)$. The group of non-AITD patients showed a higher KIR2DL3 homozygosity frequency $(63.3 \%$ vs $33.3 \%)(p=0.0379)$ and a concomitant lower KIR2DL2/DS2 homozygosity frequency (6.6\% vs $33.3 \%)$ ( $p=0.0211)$ compared to the control group. There was no significant difference in KIR2DL2/DS2/KIR2DL3 heterozygosity in the group of non-AITD patients compared to the control group (30\% vs $33.3 \%)(p=1.0000)$.

In $\mathrm{B} 19 \mathrm{~V}$ positive subjects with autoimmune disease, frequency of homozygosity for KIR2DL2/DS2 was higher than in B19V-negative subjects $(33 \%$ vs $21 \%)$. Also, KIR2DL2/DS2/KIR2DL3 heterozygosity frequency was higher in $\mathrm{B} 19 \mathrm{~V}$-positive individuals compared to negative ones (50\% vs 33\%), whereas a concomitant lower KIR2DL3 homozygosity frequency was observed (17\% vs $46 \%$ ) (Fig. 1). In addition, also by subdividing the group of patients with non-autoimmune diseases according to B19V positivity or negativity, the results showed higher frequency of homozygosity for $K I R 2 D L 2 / D S 2$, but not significantly (7\% vs 6\%), and higher KIR2DL2/DS2/KIR2DL3 heterozygosity frequency (43\% vs 19\%), and lower KIR2DL3 homozygosity frequency (50\% vs $75 \%$ ) (Fig. 1).

\section{DISCUSSION}

Natural killer (NK) cells are crucial components of the innate immune system and provide a first line of defence against infection (Vivier et al. 2011). NK cell function is regulated by a network of activating and inhibitory receptors (Middleton and Gonzelez, 2010), including KIRs. In the present study the KIR genotype of patients with thyroid gland disorders was characterised for the presence of $K I R 2 D L 2 / D S 2$ and KIR2DL3 genes, to test for any possible influence of NK receptor allotype in the risk of development of thyroid gland diseases. nPCR is an appropriate and very sensitive method for the detection of genomic sequences in DNA samples and has been used previously to detect B19V (Adamson-Small et al. 2014), KIR2DL2/DS2

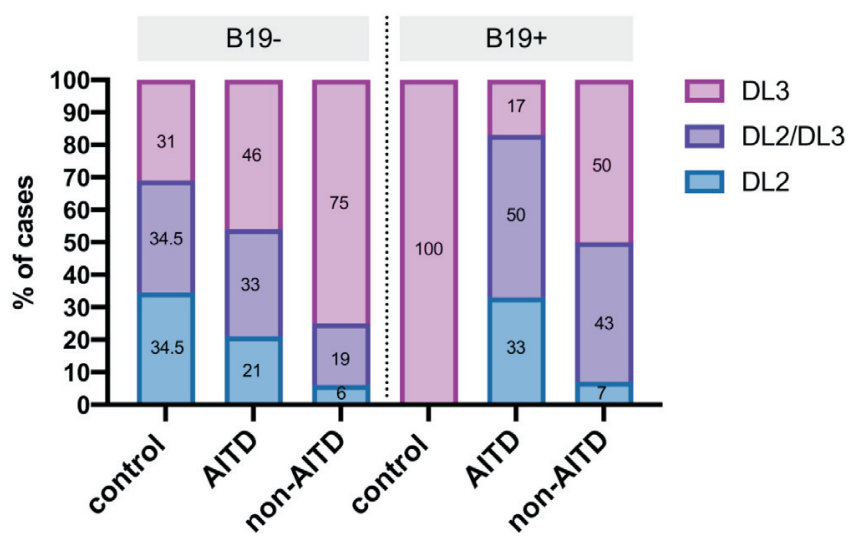

Fig. 1. Thyroid tissue subdivided for B19V positivity. KIR allotypes frequencies in patients with autoimmune thyroid diseases (AITD), non-autoimmune thyroid diseases (non-AITD) and control group subjects (Control). DL3 - KIR2DL3 homozygosity, DL2/DL3 - KIR2DL2/DS2/KIR2DL3 heterozygosity, DL2 - KIR2DL2/DS2 homozygosity.

and KIR2DL3 (Caselli et al., 2014) in various human tissues. Our results clearly showed that B19V DNA can be found in the thyroid gland independently of whether there was or was not an underlying autoimmune disease, and it was observed to be more frequent in non-AITDs than in AITD patients $-46.6 \%$ and $20 \%$, respectively; $p=0.053$. Previously it was shown that B19V can be detected in all forms of thyroid gland diseases, which leads to the idea that B19V is just an "innocent bystander" present in the thyroid, but is not involved in pathological mechanisms affecting the gland (Mori and Yoshida, 2010). Later, it was also reported that B19V was detected in a majority (87\%) of tissues examined and was not correlated with disease (Adamson et al., 2014). However, our data showed a very different prevalence of the virus in tissues of the control group (individuals whose histories did not show any of autoimmune or thyroid diseases), compared with patients with AITD or non-AITD $\left(\mathrm{Chi}^{2}, p=0.04\right.$ and $p=0.0001$, respectively). These results rather suggest that $\mathrm{B} 19 \mathrm{~V}$ might not be just an "innocent bystander", but that it might be implicated in thyroid disease.

Activating KIR2DL2/DS2 has been reportedly implicated in inflammation associated with autoimmune diseases such as systemic sclerosis, rheumatoid vasculitis, type I diabetes and systemic lupus erythematosus (Pellett et al., 2007). Specific activating KIR genes in thyroid cancer patients can generate a chronic inflammatory condition resulting in a tumour microenvironment that may favour tumour growth (Ashouri et al., 2012). Although a direct role of NK cell receptors in thyroid disease pathogenesis is unknown, the results of the KIR genotype characterisation showed different frequencies of KIR allotypes in patients with AITD and non-AITD compared to the control group. Remarkably, in B19V positive subjects with autoimmune disease, there was a higher homozygosity for KIR2DL2/DS2 (33\% vs 21\%) compared to $\mathrm{B} 19 \mathrm{~V}$ negative cases, which is important in confirming inability to control the infection. 


\section{CONCLUSION}

Overall, our data showed that B19V positive patients with AITD had higher frequency of the KIR2DL2/DS2 allele (both for homozygosity and heterozygosity), suggesting impairment of NK cell function, which might allow virus replication and pathogenic effect. Further studies are however needed to characterise the contribution of B19V and KIR in defining susceptibility to thyroid disease. Further studies are also needed with larger groups of patients in order to be able to perform a more accurate statistical analysis.

\section{REFERENCES}

Adamson-Small, L. A., Ignatovich, I. V., Laemmerhirt, M. G., Hobbs, J. A. (2014). Persistent parvovirus B19 infection in non-erythroid tissues: Possible role in the inflammatory and disease process. Virus Res., 190, 8-16.

Adamson, L. A., Fowler, L. J., Ewald, A. S., Clare-Salzler, M. J., Hobbs, J. A. (2014). Infection and persistence of erythrovirus B19 in benign and cancerous thyroid tissues. J. Med. Virol., 86, 1614-1620.

Ashouri, E., Dabbaghmanesh, M. H., Rowhanirad, S., Bakhshayeshkaram, M., Ranjbar Omrani, G., Ghaderi, A. (2012). Activating KIR2DS5 receptor is a risk for thyroid cancer. Hum. Immunol., 73, 1017-1022.

Barah, F., Vallely, P. J., Chiswick, M. L., Cleator, G. M., Kerr, J. R. (2001). Association of human parvovirus B19 infection with acute meningoencephalitis. Lancet, 358, 729-730.

Borghi, A., D’Accolti, M., Rizzo, R., Virgili, A., Di Luca, D., Corazza, M., Caselli, E. (2016). High prevalence of specific KIR types in patients with HHV-8 positive cutaneous vascular lesions: A possible predisposing factor? Arch. Dermatol. Res., 308, 373-77.

Caselli, E., Rizzo, R., Ingianni, A., Contini, P., Pompei, R., Di Luca, D. (2014). High prevalence of HHV8 infection and specific killer cell immunoglobulin-like receptors allotypes in Sardinian patients with type 2 diabetes mellitus'. J. Med. Virol., 86, 1745-1751.

Desailloud, R., Hober, D. (2009). Viruses and thyroiditis: An update. Virol. $J ., 6,5$

Ferrari, S. M., Fallahi, P., Antonelli, A., Benvenga, S. (2017). Environmental issues in thyroid diseases. Front Endocrinol. (Lausanne), 8, 50.

Fogel, L. A., Yokoyama, W. M., French, A. R. (2013). Natural killer cells in human autoimmune disorders. Arthritis Res. Ther., 15, 216.

Fusco, C., Guerini, F. R., Nocera, G., Ventrella, G., Caputo, D., Valentino, M. A., Agliardi, C., Gallotti, J., Morra, V. B., Florio, C., Clerici, M., Lombardi, M. L. (2010). KIRs and their HLA ligands in remitting-relapsing multiple sclerosis. J. Neuroimmunol., 229, 232-237.
Gómez-Lozano, N., Gardiner, C. M., Parham, P., Vilches, C. (2002). Some human KIR haplotypes contain two KIR2DL5 genes: KIR2DL5A and KIR2DL5B. Immunogenetics, 54, 314-319.

Heegaard, E. D., Brown, K. E. (2002). Human parvovirus B19. Clin. Microbiol. Rev., 15, 485-505.

Kozireva, S. V., Zestkova, J. V., Mikazane, H. J., Kadisa, A. L., Kakurina, N. A., Lejnieks, A. A., Danilane, I. N., Murovska, M. F. (2008). Incidence and clinical significance of parvovirus B19 infection in patients with rheumatoid arthritis. J. Rheumatol., 35, 1265-1270.

Marsh, S. G., Parham, P., Dupont, B., Geraghty, D. E., Trowsdale, J., Middleton, D., Vilches, C., Carrington, M., Witt, C., Guethlein, L. A., Shilling, H., Garcia, C. A., Hsu, K. C., Wain, H. (2003). Killer-cell immunoglobulin-like receptor (KIR) nomenclature report, 2002. Tissue Antigens, 62, 79-86.

Middleton, D., Gonzelez, F. (2010). The extensive polymorphism of KIR genes. Immunology, 129, 8-19.

Mori, K., Yoshida, K. (2010). Viral infection in induction of Hashimoto's thyroiditis: A key player or just a bystander? Curr. Opin. Endocrinol. Diabetes Obes., 17, 418-424.

Naciute, M., Mieliauskaite, D., Rugiene, R., Nikitenkiene, R., Jancoriene, L., Mauricas, M., Nora-Krukle, Z., Murovska, M., Girkontaite, I. (2016). Frequency and significance of parvovirus B19 infection in patients with rheumatoid arthritis. J. Gen. Virol., 97, 3302-3312.

Page, C., Duverlie, G., Sevestre, H., Desailloud, R. (2015). Erythrovirus B19 and autoimmune thyroid diseases. Review of the literature and pathophysiological hypotheses. J. Med. Virol., 87, 162-169.

Pellett, F., Siannis, F., Vukin, I., Lee, P., Urowitz, M. B., Gladman, D. D. (2007). KIRs and autoimmune disease: studies in systemic lupus erythematosus and scleroderma. Tissue Antigens, 69 (Suppl 1.), 106-108.

Saiki, R. K., Gelfand, D. H., Stoffel, S., Scharf, S. J., Higuchi, R., Horn, G. T., Mullis, K. B., Erlich, H. A. (1988). Primer-directed enzymatic amplification of DNA with a thermostable DNA polymerase. Science, 239, 487-491.

Vilches, C., Parham, P. (2002). KIR: Diverse, rapidly evolving receptors of innate and adaptive immunity. Annu. Rev. Immunol., 20, 217-251.

Vivier, E., Raulet, D. H., Moretta, A., Caligiuri, M. A., Zitvogel, L., Lanier, L. L., Yokoyama, W. M., Ugolini, S. (2011). Innate or adaptive immunity? The example of natural killer cells. Science, 331, 44-49.

Wang, J., Zhang, W., Liu, H., Wang, D., Wang, W., Li, Y., Wang, Z., Wang, L., Zhang, W., Huang, G. (2010). Parvovirus B19 infection associated with Hashimoto's thyroiditis in adults. J. Infect., 60, 360-370.

Wilson, M. J., Torkar, M., Haude, A., Milne, S., Jones, T., Sheer, D., Beck, S., Trowsdale, J. (2000). Plasticity in the organization and sequences of human KIR/ILT gene families. Proc. Natl. Acad. Sci. USA, 97, 4778-4783.

Received 26 July 2020

Accepted in the final form 12 January 2021

\section{KIR2DL2/DS2 UN KIR2DL3 IZPLATĪBA UN B19V KLĀTBŪTNE PACIENTIEM AR VAIROGDZIEDZERA SLIMĪBĀM}

Dabisko galētājšūnu (naturālo killeru, NK) funkciju kontrolē plašs spektrs antigēnu receptoru, kā vieni no tiem tiek minēti galētājšūnu imūnglobulīniem līdzīgie receptori (KIR), kurus kontrolē gēnu saime, kas lokalizēta vienā no mainīgākajiem reǵioniem cilvēka genomā — hromosomā 19q13.4. Šì pētījuma mērkis bija noskaidrot iespējamo mijiedarbību starp KIR allotipu, parvovīrusa B19 (B19V) infekciju un vairogdziedzera slimībām. Pētījumā iekḷāva vairogdziedzera audus no 30 pacientiem ar autoimūnajām vairogdziedzera slimībām (AITD), 30 pacientiem ar vairogdziedzera slimībām bez autoimunitātes klātbūtnes (ne-AITD) un 30 mirušiem indivīdiem, kuru slimības vēsturē nebija datu par AITD vai ne-AITD. B19V, KIR2DL2/DS2 un KIR2DL3 klātbūtni noteica, izmantojot polimerāzes kēêdes reakcijas (nPCR, PCR). B19V genoma sekvenci vairogdziedzera audu DNS paraugos konstatēja 28\% pacientu ar AITD, 67\% ar ne-AITD un tikai 5\% kontroles grupas indivīdu. B19V pozitīviem AITD pacientiem KIR2DL2/DS2 homozigotitāte bija biežāk sastopama un KIR2DL3 homozigotitāte - retāk, salīdzinot ar B19V negatīvajiem (attiecīgi 33\% pret 21\% un 17\% pret 46\%). Lai gan mūsu dati rāda, ka B19V pozitīviem pacientiem ar AITD ir palielinājusies homozigotitāte attiecībā uz KIR2DL2/DS2, pētījums ir jāturpina, palielinot pacientu grupu, lai raksturotu KIR2DL2/DS2 nozīmi uzṇēmībā pret vairogdziedzera slimībām. 